\title{
INTEGRASI MEDIASI PENAL \\ DALAM PEMBAHARUAN SISTEM PERADILAN PIDANA INDONESIA
}

Sejalan dengan semangat dunia internasional untuk menerapkan mediasi penal dalam sistem peradilan pidana, diskursus serupa juga mulai berkembang di Indonesia. Konsep ini oleh para ahli hukum dipandang sangat relevan dan cocok untuk diberlakukan di Indonesia.

Pembaharuan sistem peradilan pidana dengan mengintegrasikan mediasi penal perlu dilakukan untuk mewujudkan sistem peradilan pidana bangsa Indonesia yang progresif dengan berlandaskan pada nilai-nilai luhur Pancasila.

Meskipun mediasi penal memiliki kesamaan dengan corak penyelesaian sengketa bangsa Indonesia, tetapi gagasan ini sepenuhnya berasal dari luar konsep hukum dan bangsa Indonesia. Untuk itulah buku ini hadir dan mengulas secara lebih mendalam mengenai mediasi penal yang diharapkan mampu membawa perubahan atas sistem peradilan pidana Indonesia menuju ke arah sistem peradilan yang dinamis dan progresif.

Buku ini sangat cocok dibaca oleh semua kalangan dan dapat dijadikan sebagai salah satu acuan dalam rangka upaya untuk melakukan pembaharuan sistem peradilan pidana di Indonesia. Terlebih bagi kalangan akademisi dan semua pihak yang ingin lebih mendalami mediasi penal dalam hubungannya dengan keinginan untuk mewujudkan keadilan restoratif di Indonesia.

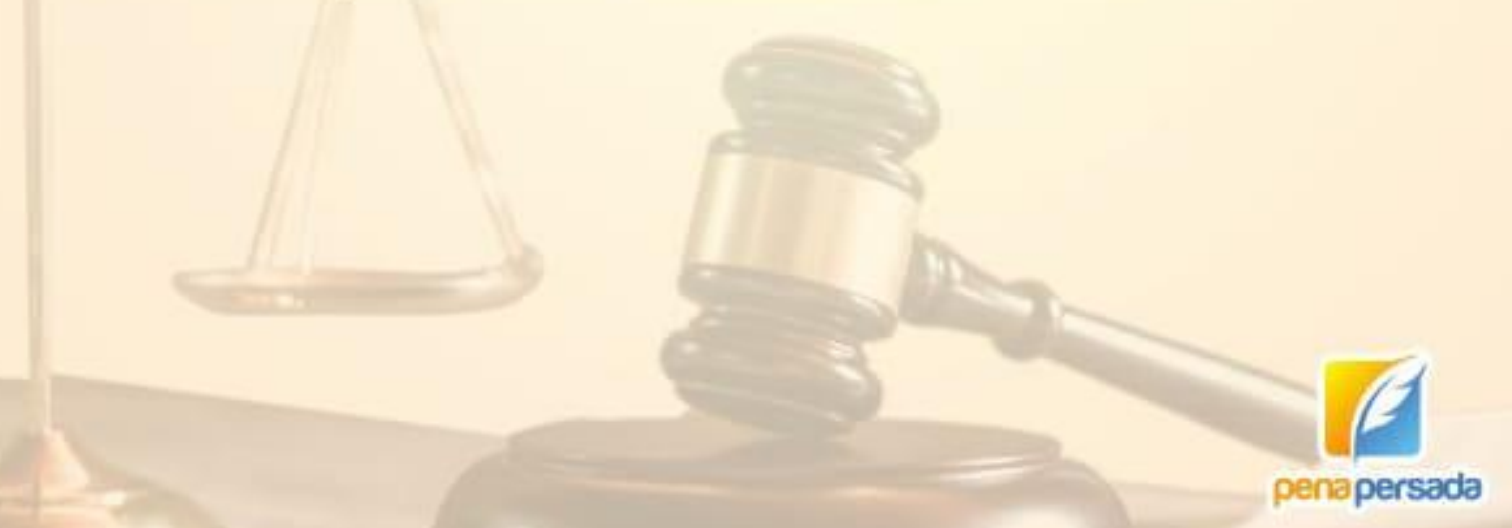

\section{INTEGRASI MEDIASI PENAL DALAM PEMBAHARUAN SISTEM PERADILAN PIDANA INDONESIA}




\section{INTEGRASI MEDIASI PENAL \\ DALAM PEMBAHARUAN \\ SISTEM PERADILAN PIDANA INDONESIA}

CSA TEDDY LESMANA, SH., MH.

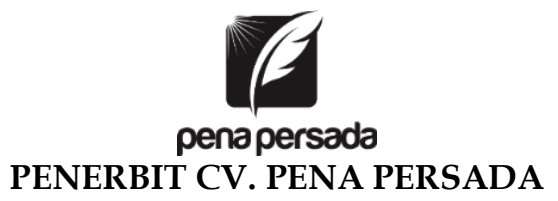




\section{INTEGRASI \\ MEDIASI PENAL \\ DALAM PEMBAHARUAN \\ SISTEM PERADILAN PIDANA INDONESIA}

Penulis:

CSA Teddy Lesmana, SH., MH.

ISBN : 978-623-315-086-6

Design Cover :

Retnani Nur Briliant

Layout :

Nisa Falahia

\section{Penerbit CV. Pena Persada}

Redaksi :

Jl. Gerilya No. 292 Purwokerto Selatan, Kab. Banyumas

Jawa Tengah

Email : penerbit.penapersada@gmail.com

Website : penapersada.com Phone : (0281) 7771388

Anggota IKAPI

All right reserved

Cetakan pertama : 2020

Hak Cipta dilindungi oleh undang-undang. Dilarang memperbanyak karya tulis ini dalam bentuk apapun tanpa izin penerbit 


\section{KATA PENGANTAR}

Sejalan dengan semangat dunia internasional untuk menerapkan mediasi penal dalam sistem peradilan pidana, diskursus serupa juga mulai berkembang di Indonesia. Konsep ini oleh para ahli hukum dipandang sangat relevan dan cocok untuk diberlakukan di Indonesia. Oleh karena itu, buku yang berjudul “Integrasi Mediasi Penal dalam Pembaharuan Sistem Peradilan Pidana" ini merupakan suatu pengantar dari penulis mengenai konsep dan gagasan mediasi penal sebagai sebuah hal penting untuk diintegrasikan ke dalam sistem peradilan pidana Indonesia di masa mendatang.

Buku ini menguraikan mengenai mediasi penal sebagai sebuah institusi alternatif penyelesaian terhadap perkara pidana yang diadakan seiring terjadinya pergeseran paradigma penegakan hukum pidana dari prinsip keadilan retributif menjadi keadilan restoratif. Di Indonesia, prinsip-prinsip mediasi penal merupakan corak utama bangsa Indonesia dalam menyelesaikan persoalan sosialnya. Sehingga baik secara filosofis, yuridis maupun sosiologis, mengintegrasikan mediasi penal dengan sistem peradilan pidana di Indonesia sangat dimungkinkan.

Oleh karena itu, penulis berharap kiranya buku ini dapat dijadikan sebagai salah satu acuan dalam rangka upaya untuk melakukan pembaharuan sistem peradilan pidana di Indonesia. Terlebih bagi kalangan akademisi dan semua pihak yang ingin lebih mendalami mediasi penal dalam hubungannya dengan keinginan untuk mewujudkan keadilan restoratif di Indonesia.

Penulis sadar bahwa dengan segala keterbatasan pengetahuan, tentu saja buku ini masih jauh dari kata sempurna. Untuk itu penulis sangat mengharapkan kritik dan saran yang konstruktif demi perbaikan dan penyempurnaannya di kemudian hari. Sebagaimana pepatah mengatakan mengatakan "life of the law has not been logic, but experience", kiranya tidaklah berlebihan jika penulis berharap bahwa buku ini semata-mata tidak dianggap sebagai logika kebenaran yang ingin dianggap mutlak, melainkan sebagai suatu upaya menambah pengalaman yang akan dilakukan 
terus menerus, hingga sampai pada kebenaran hakiki, kebenaran Yang Maha Kecuali.

Akhirnya penulis ucapkan terima kasih kepada semua pihak yang telah memberikan bantuan dan dorongan atas terbitnya buku ini, semoga menjadi amal kebaikan bagi kita semua.

Sukabumi, Desember 2020

Penulis 


\section{DAFTAR ISI}

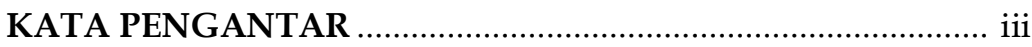

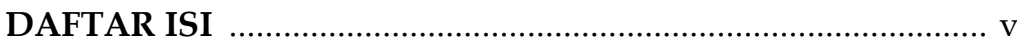

BAB I PENDAHULUAN ....................................................... 1

A. Pembaharuan Sistem Peradilan Pidana Suatu

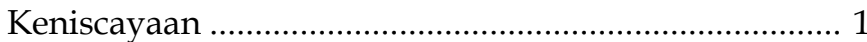

B. Pengertian Mediasi Penal dalam Perspektif Istilah dan Teori Hukum

BAB II UPAYA PEMBAHARUAN SISTEM PERADILAN

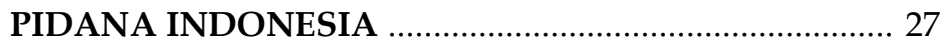

A. Sistem Peradilan Pidana (Criminal Justice System) ......... 27

B. Konsep, Asas dan Realita Pendekatan Sistem dalam Peradilan Pidana Indonesia 41

\section{BAB III MEDIASI PENAL SEBAGAI ALTERNATIF} PENYELESAIAN DALAM PERKARA PIDANA

A. Perkembangan Gagasan Mediasi Penal Sebagai Pilihan Penyelesaian Sengketa 53

B. Mediasi Penal dalam Perspektif Teori Keadilan Restoratif (Restorative Justice)

C. Prinsip-Prinsip dan Model Pelaksanaan Mediasi Penal

D. Pola Implementasi Mediasi Penal di Beberapa Negara 81

E. Nilai Kekuatan Kesepakatan Mediasi Penal

BAB IV ALTERNATIF PENYELESAIAN PERKARA PIDANA DAN PROSPEK INTEGRASI MEDIASI PENAL DI INDONESIA

A. Karakteristik Alternatif Penyelesaian Sengketa Pidana di Indonesia 85

B. Prospek Integrasi Model Mediasi Penal di Indonesia ... 109

BAB V INTEGRASI MEDIASI PENALDALAM SISTEM PERADILA PIDANA INDONESIA

A. Integrasi Mediasi Penal Menuju Sistem Peradilan Pidana Melalui Pembaharuan Konseptual yang Progresif 
B. Konstruksi Kebijakan Hukum Pidana Terhadap

Model Mediasi Penal dalam Sistem Peradilan

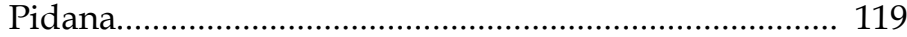

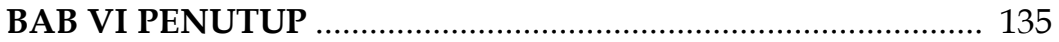

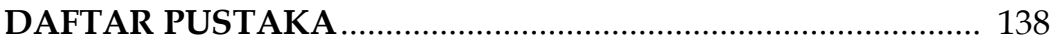

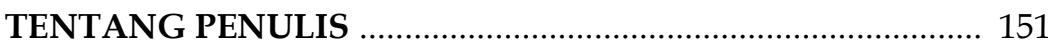




\section{BAB I \\ PENDAHULUAN}

\section{A. Pembaharuan Sistem Peradilan Pidana Suatu Keniscayaan}

Diskursus serta wacana yang dibangun guna mendukung niat untuk melakukan perubahan terhadap Sistem Peradilan Pidana (criminal justice system) ${ }^{1}$ terus berkembang mengikuti pola dan dinamika dalam sistem kehidupan masyarakat. Banyak gagasan bermunculan seiring dengan beragam perspektif yang digunakan dalam rangka mendukung argumentasi yang dikemukakan. Tentu saja keragaman itu dipengaruhi pula oleh latar belakang dari masing-masing pengusung gagasan tersebut. Namun demikian dalam perkembangannya dewasa ini, gagasan dan wacana yang muncul itu masih terbukti belum banyak memberikan perubahan yang fundamental atas "karakteristik tradisional"2 yang telah ternyata melekat pada sifat utama sistem peradilan

1 Istilah "criminal justice system" (sistem peradilan pidana) untuk pertama kali diperkenalkan oleh para pakar hukum pidana dan ahli hukum dalam "criminal justice science" di Amerika Serikat serikat sekitar Tahun 1960-an. Konsep sistem peradilan pidana ini diperkenalkan sebagai akibat dari ketidakpuasan atas bentuk "law and order approach" dimana penegakan hukum hanya mengandalkan efektivitas kinerja kepolisian. Dengan konsep'sistem' ini, penegakan hukum menitik beratkan pada integrasi, koordinasi dan sinkronisasi antara kinerja kepolisian, kejaksaan, pengadilan dan lembaga pemasyarakatan. Lihat Romli Atmasasmita, Sistem Peradilan Pidana Kontemporer, Kencana, Jakarta, 2010, hal. 27-30.

2 Sifat peradilan pidana yang sangat tradisional misalnya terlihat dari tujuan dibentuknya hukum acara pidana, yakni untuk "mencari dan mendapatkan atau setidak-tidaknya mendekati kebenaran meteriil" namun dengan menggunakan cara-cara yang formil. Cara-cara formil ini menurut de Bosch Kemper tidak lain dari cara negara untuk menjalankan haknya karena telah terjadi pelanggaran atas undang-undang pidana. Dengan demikian, peradilan pidana mutlak menjadi milik atau setidak-tidaknya dibawah kendali negara secara keseluruhannya. Lalu bagaimana mungkin akan didapatkan sebuah kebenaran materil jika negara hanya mengandalkan cara-cara verbal yang bersifat formal. Lagipula, tujuan ditemukannya kebenaran meteril adalah semata-mata untuk menjatuhkan hukuman yang secara legal formal telah diatur dalam peraturan perundang-undangan. Tegasnya, dalam pandangan tradisional bahwa tujuan utama peradilan pidana adalah untuk memidanakan seorang pelaku tindak pidana. Bandingkan dengan Andi Hamzah, Hukum Acara Pidana, Edisi Kedua, Sinar Grafika, Jakarta, 2008, hal. 7-9. 
pidana dalam sistem hukum di berbagai negara pada umumnya.

Sulitnya merubah karakteristik tradisional dalam sistem peradilan pidana, baik di negara penganut sistem hukum civil law bahkan dalam sistem hukum common law sendiri, pada dasarnya disebabkan oleh sifat hukum pidana itu sendiri yang terlanjur telah disepakati dan dibakukan sebagai bagian dari hukum publik (algemene belangen). Dengan bentuk dan sifat ini, bagaimanapun juga tingkat fleksibelitas kaedah-kaedah pidana itu disusun dan diberlakukan, pada akhirnya tetap saja menghasilkan polarisasi 'kaku', yakni sedikitnya (jika enggan untuk menyebut tidak ada) peranan individu, di mana penegakan hukum hanya bertumpu pada negara sebagai yang terutama bagi penentu dan pemberi rasa keadilan. ${ }^{3}$

Polarisasi yang demikian itu dapat dipahami sebagai pengejawantahan konsep hukum dalam hubungannya dengan gagasan untuk mendapatkan suatu keadilan yang sempurna. Konsep dasar mengenai keadilan ini dicetuskan oleh Plato yang pada intinya menekankan bahwa dalam hukum sebagai suatu tatanan moral dan etika pertama-tama diupayakan dan menitik beratkan pada kepentingan umum sebagai yang diutamakan. ${ }^{4}$

Kepentingan umum yang dimaksud oleh konsep ini adalah adanya partisipasi semua orang dalam gagasan serta upaya-upaya untuk memperoleh keadilan melalui keterwakilannya dalam perangkat-perangkat negara, sehingga wujud

3 Penghilangan peranan individu melalui mekanisme yang dianut dalam sistem peradilan pidana dibangun berdasarkan sebuah doktrin bahwa "pemerintah atau negara senantiasa berbuat baik terhadap warganya", sehingga sengketa pidana dipandang merupakan sengketa individu dengan masyarakat (negara) yang wajib diselesaikan oleh negara sebagai wakil dari masyarakat (publik). Lihat Luhut M.P Pangaribuan, Hukum Acara Pidana Surat-Surat Resmi Di Pengadilan Oleh Advokat; Praperadilan, Eksepsi, Pledoi, Duplik, Memori Banding Kasasi, Peninjauan Kembali, Edisi Revisi, Djambatan, Jakarta, 2006, hal. 1.

4 Lihat Garuda Wiko, "Pembangunan Sisten Hukum Berkeadilan" dalam Memahami Hukum Dari Konstruksi sampai Implementasi, Editor Satya Arinanto dan Ninuk Triyanti, Rajawali Pers, Jakarta, 2009, hal. 10. 
keadilan akan diperoleh secara sempurna. Konsekuensi dari konsep ini adalah bahwa negara yang menetapkan normanorma keadilan, negara yang membentuk sekaligus pelaksana dari mekanisme pencarian keadilan, sehingga pada gilirannya negara pula lah yang memutuskan atau memberikan keadilan.

Demikian halnya dalam hukum pidana, perbuatan pidana dipandang sebagai suatu tindakan yang merusak atau merugikan kepentingan orang lain, dan dengannya menjadi dasar bagi korban sebagai pihak yang dirugikan untuk melakukan suatu pembalasan kepada pihak yang merugikannya. Dalam perspektif kehidupan bersama pada suatu masyarakat, pembalasan tersebut umumnya tidak hanya menjadi hak dari korban tindak pidana itu semata, tetapi berkembang menjadi kewajiban bersama seluruh keluarga, bahkan dalam beberapa dimensi dan peristiwa-peristiwa tertentu, hal tersebut dipandang sebagai kewajiban dari masyarakat. Sehingga akhirnya pemenuhan pembalasan tersebut menjadi bagian dari tanggung jawab bahkan tujuan diadakannya suatu negara.

Konsep ini telah dan sedang berlaku di Indonesia paling tidak sejak diundangkannya Kitab Undang-Undang Hukum Acara Pidana (yang selanjutnya cukup ditulis KUHAP) melalui Undang-Undang Nomor 8 Tahun 1981 tentang Hukum Acara Pidana. Bahkan dalam konteks hukum kolonial, konsep dan mekanisme ini telah berlaku sejak Indonesia masih dalam penjajahan Belanda, juga setelah kemerdekaan ketika masih menggunakan Het Herziene Inlandsch Reglemen (HIR) yang kemudian diperbaharui dengan Reglement Indonesia yang diperbaharui (RIB) peninggalan Belanda sebagai Hukum Acara Pidana. $^{5}$

${ }_{5}$ HIR/RIB mulai mulai berlaku sejak 1 Mei 1848, yang kemudian ditiru dalam menyusun RBg yang berlaku sejak 1 Juli 1927, tentu saja disusun sesuai dengan kondisi masyarakat Indonesia masa itu, yang sebagian besar tidak bisa membaca dan menulis, sehingga bentuk-bentuk hukum acara ketika itu sangatlah sederhana, walau tidak terlalu formalistik seperti KUHAP sekarang, namun 
Memperhatikan secara seksama sistem peradilan pidana yang dianut KUHAP, dapatlah dikatakan bahwa sistem peradilan pidana Indonesia telah mengurangi jika enggan untuk menyebut menghilangkan peranan penting individu dalam upaya penyelesaian perkara pidana. Pencarian keadilan dalam perkara pidana sepenuhnya bertumpu pada kemampuan dari integrasi sistem yang dibangun oleh kepolisian, kejaksaan, pengadilan dan lembaga pemasyarakatan. Bahkan, setelah lahirnya Undang-Undang Nomor 18 Tahun 2003 tentang Advokat, yang semula diharapkan dapat memperbesar peran individu melalui pendampingan korban dan upaya-upaya di luar pengadilan, ternyata tidak merubah sifat ' $k a k u$ ' pada sistem peradilan pidana Indonesia. Advokat baru akan berdaya guna dan dinilai perbuatannya dalam rangka mencari keadilan, hanya atas tindakannya di muka persidangan dalam pengadilan. Sementara hasil upaya yang dilakukan diluar pengadilan, seperti hasil perundingan dan perdamaian tidak memiliki kekuatan hukum untuk dinilai sebagai bahan pertimbangan suatu putusan sidang pengadilan. ${ }^{6}$

peranan individu yang diberikan ketentuan-ketentuan tersebut justru sama sekali tidak ada. Selanjutnya berdasarkan Aturan Peralihan dalam Undang-Undang Dasar 1945, Konstitusi RIS 1949, dan Undang-Undang Dasar Sementara 1950, setelah Indonesia merdeka HIR/RIB berlaku sampai akhirnya dikeluarkan UndangUndang Nomor 8 Tahun 1981 tentang Hukum Acara Pidana. Yahya Harahap memandang bahwa "lahirnya KUHAP telah mengangkat dan menempatkan seorang manusia dalam kedudukan yang bermartabat sebagai makhluk ciptaan Tuhan", tetapi tidak pula memberikan ruang bagi seorang manusia itu sendiri untuk mengupayakan keadilan yang ingin diterimanya. Lihat M. Yahya Harahap, Pembahasan Permasalahan dan Penerapan KUHAP Penyidikan dan Penuntutan, Edisi ke2, Cet. 8, Sinar Grapika, Jakarta 2006, hal. 1-2.

6 Undang-Undang Advokat memiliki cita-cita untuk semakin menegaskan serta mengejawantahkan sebuah prinsip dalam negara hukum yakni "adanya jaminan kesederajatan bagi setiap orang di hadapan hukum (equality before the law)", Lihat, Alinea Pertama Penjelasan Umum, Penjelasan Atas Undang-Undang Republik Indonesia Nomor 18 Tahun 2003 Tentang Advokat. Bandingkan dengan kebebasan Advokat yang diatur dalam Pasal 14 undang-undang ini yang menentukan bahwa "Advokat bebas mengeluarkan pendapat atau pernyataan dalam membela perkara yang menjadi tanggung jawabnya di dalam sidang pengadilan dengan tetap berpegang pada kode etik profesi dan peraturan perundang-undangan". Tidak ada aturan lebih lanjut mengenai kebebasan Advokat 
Sistem peradilan pidana Indonesia yang demikian itu jelas relevan dengan teori keadilan sempurna yang dimaksud oleh Plato sebagaimana telah diuraikan di atas. Padahal seiring berjalannya waktu serta perubahan dinamika masyarakat Indonesia dan dunia umumnya, perbuatan-perbuatan pidana pun semakin berkembang dan dirasakan kompleksitasnya mulai dari bentuk, kualifikasi sampai dengan akibat yang ditimbulkan oleh perbuatan tersebut. Kaedah-kaedah pidana tidak lagi parsial dalam sifat publiknya, melainkan cenderung dan relatif bergeser memasuki ranah privat. Dalam konteks ini, tentu upaya-upaya pencarian keadilan tidak dapat lagi hanya bertumpu pada negara dengan prosedur legal formal dan proses verbal semata-mata, melainkan harus diupayakan melalui hubungan-hubungan dan kerja sama sosial yang lebih kompetitif. Dalam hal ini, tepatlah bilamana merujuk pada konsep keadilan yang seimbang dengan mengutamakan kesempurnaan prosedur tawar-menawar yang fair antar individu sebagaiamana yang dikemukakan oleh John Rawls berikut ini:

Prinsip keadilan adalah hasil dari persetujuan dan tawarmenawar yang fair. Karena dengan adanya situasi posisi asali (para pihak tidak dikondisikan oleh suatu sistem negara - Penulis), relasi semua orang yang simetri, maka situasi awal ini adalah fair antar individu sebagaimana person moral, yakni sebagai makhluk rasional dengan tujuan dan kemampuan mereka mengenali rasa keadilan. Posisi asali ini dapat dikatakan merupakan status quo awal yang pas, sehingga persetujuan fundamental yang dicapai di dalamnya adalah fair ... .

di luar pengadilan yang dapat dijadikan sebagai pertimbangan hukum dalam menyelesaikan suatu perkara. Apalagi dengan konfigurasi sitem peradilan pidana Indonesia saat ini dimana korban diwakili oleh negara, maka betapapun Advokat dilindungi hukum untuk mendampingi seorang terdakwa, tetap saja kedudukan antara orang yang mencari keadilan tersebut tidak sebanding. Bandingkan dengan Artidjo Alkostar, Peran dan Tantangan Advokat Dalam Era Globalisasi, FH UII Press, Yogyakarta, 2010, hal. 152-153.

7 John Rawls, A Theory of Justice (Teori Keadilan), diterjemahkan oleh Uzair Fauzan dan Heru Prasetyo, Pustaka Pelajar, Yogyakarta, 2006, hal. 13-14. 
Tegasnya, keadilan dicapai melalui sebuah kesepakatan yang diambil oleh pihak-pihak yang berperkara dan bukan diberikan oleh negara. Karena keadilan yang diberikan oleh negara tersebut belum tentu bahkan seringkali tidak sesuai dengan kehendak bebas para pencari keadilan itu sendiri, sebab pada dasarnya setiap orang membutuhkan dan mengejar kepentingan mereka serta dengan tingkat akseptabilitas yang beragam atas rasa keadilan. Keadilan semacam ini tidak akan pernah ditemukan dalam grand design sistem peradilan pidana Indonesia yang berlaku sekarang.

Keadilan yang fair sebagaimana dipahami hanya mungkin dapat dicapai melalui kesepakatan para pihak yang berperkara, tentu memerlukan suatu mekanisme yang mampu untuk mempertemukan kepentingan-kepentingan serta menghasilkan keputusan yang disepakati bersama. Salah satu konsep untuk mewujudkan gagasan tersebut adalah sistem mediasi sebagai upaya penyelesaian perkara selain melalui proses di sidang pengadilan yang dikenal dengan istilah "mediasi penal" (penal mediation), yang selama ini hanya dikenal sebagai alternative dispute resolution (ADR) dalam ranah hukum privat (bijzondere belangen).

Memang gagasan mediasi penal sebagai alternatif penyelesaian perkara pidana selain melalui proses di sidang pengadilan ini, tidak pernah dikenal sebelumnya baik dalam sistem peradilan dengan model "due process of law" maupun dalam "crime control model"8. Jikapun ada upaya-upaya

8 The Crime Control Model didasarkan atas anggapan bahwa penyelengaraan peradilan pidana adalah semata-mata untuk menindas pelaku kriminal (Criminal Conduct) yang adalah juga merupakan tujuan utama dari proses peradilan pidana, oleh sebab dalam hal ini yang diutamakan adalah ketertiban umum (Public Order) dan efesiensi. Kedudukan pelaku tindak pidana dalam model ini selalu diperlakukan sebagai "Presumtion Of Guilty" (praduga bersalah). Sementara dalam The Due Process Model terkandung sikap batin penghormatan terhadap manusia. Model ini melambangkan sikap yang sangat dalam tentang keadilan bagi sesama manusia dan antara individu dengan masyarakat dan pemerintah (negara). Sehingga dalam model ini, kedudukan seseorang yang sedang diproses dalam peradilan pidana berada pada apa yang dinamakan dengan "Presumtion Of Inocence" (praduga tidak bersalah). Model ini didasarkan kepada 
penyelesaian suatu perkara pidana di luar pengadilan, khususnya dalam konteks praktek penegakan hukum pidana di Indonesia, semua itu sematamata bersifat atau melalui diskresi aparat penegak hukum. Misalnya dengan upaya pendahuluan untuk mengupayakan perdamaian, penyelesaian melalui lembaga adat dan lain sebagainya.

Upaya-upaya tersebut dilakukan hanya terbatas sebagai "upaya pendahuluan" yang "mubadzir" karena tidak memiliki kekuatan hukum mengikat untuk kemudian tetap melanjutkan proses penyelesaian perkara tersebut melalui sidang di pengadilan. Kalaupun diperoleh sebuah kesepakatan atau putusan lembaga adat, semua itu hanya akan dijadikan "sebagai dasar pertimbangan yang tidak mengikat" oleh hakim pengadilan, dalam arti upaya diluar pengadilan yang telah dilakukan tidak menyelesaikan persoalan. ${ }^{9}$ Sebaliknya perspektif hukum pidana yang lebih sensitif, hal tersebut justru telah menciderai azas "nebis in idem"10 dalam pengertian yang

"Obstacle Course", dengannya maka petugas dalam melaksanakan tugasnya didasarkan kepada aturan main yang ada, dan yang telah ditentukan sebelumnya. Namun di Indonesia, baik dalam dimensi teoritis maupun praktiknya, kedua model ini seringkali sulit untuk dibedakan. Satu hal yang sama dari kedua sistem tersebut adalah dimana sistem peradilan pidana dibentuk, dilaksanakan, dan dikuasai secara mutlak oleh negara. Lihat Herbert L. Packer, The Limit of Criminal Sanction, Stanford University Press, California, 1969, hal. 153. Lihat Juga dalam Yesmil Anwar dan Adang, Sistem Peradilan Pidana; Konsep, Komponen \& Pelaksanaannya Dalam Penegakan Hukum di Indonesia, Cetakan Kedua, Widya Padjajaran, Bandung, 2011, hal. 39-47.

9 Dalam putusan-putusan hakim pengadilan yang mengadili perkara pidana, hampir tidak pernah ditemukan dasar pertimbangan yang menyebutkan atau mengikutsertakan hukum adat atau hasil persidangan adat, sebagai alasan bagi hakim untuk mengambil keputusannya atau sekedar sebagai hal-hal yang meringankan saja. Praktik-praktik seperti ini tidak hanya terjadi pada pengadilan tingkat pertama dan banding, melainkan terjadi juga pada putusan-putusan Mahkamah Agung di tingkat Kasasi dan Peninjauan Kembali. Tetapi untuk beberapa perkara perdata, seringkali hakim mendasarkan putusannya atas pengikutsertaan hukum adat sebagai bahan yang dipertimbangkan. Praktik penegakan hukum semacam ini, seakan-akan menganggap bahwa hukum adat Indonesia tidak berlaku atau setidak-tidaknya dikenal dalam hukum pidana Indonesia. Bandingkan dengan Sulistyowati Irianto dan Antonius Cahyadi, Runtuhnya Sekat Perdata dan Pidana; Studi Peradilan Kasus Kekerasan Terhadap Perempuan, Yayasan Obor, Jakarta, 2008, hal. 31.

10 Secara sempit, azas nebis in idem diartikan oleh Mahkamah Agung melalui Surat Edaran Mahkamah Agung Nomor 3 Tahun 2002 sebagai perkara 
luas. Hal ini dikarenakan seseorang yang dituduh melakukan suatu tindak pidana harus mengalami lebih dari satu kali 'penghakiman' (penuntutan) dalam satu perkara yang sama, yang mana telah ternyata tidak dibenarkan oleh kaedah hukum pidana itu sendiri sebagaimana dikenal dalam adagium "nemo debet bis vexari pro una et eadem causa, en nemo debet bis puniri pro uno delicto". 11

Di satu sisi, meningkatnya volume perkara dengan beragam jenisnya yang diajukan ke pengadilan tentu saja menjadi beban bagi pengadilan untuk melakukan pemeriksaan dan mengadilinya. Kemampuan organisasi pengadilan yang terbatas baik secara tekhnis maupun sumber daya manusia di pengadilan itu sendiri, pada gilirannya sering menimbulkan penumpukan kasus di pengadilan, dan akan serta telah pula berpengaruh pada kualitas suatu putusan hakim. ${ }^{12} \mathrm{Hal}$ ini tentu

dengan obyek dan subyek yang sama dan telah diputus serta mempunyai kekuatan hukum tetap baik dari tingkat judex factie sampai denga tingkat kasasi baik dari lingkuangan Peradilan Umum, Peradilan Agama, dan Peradilan Tata Usaha Negara. Memang tidak disebutkan bahwa Peradilan Adat merupakan bagian dari proses peradilan yang dimaksud, tetapi di beberapa daerah seperti Aceh, peradilan adat justru peradilan yang pertama-tama menangani suatu perkara. Dalam hal ini, azas nebis in idem selayaknya diartikan secara luas yakni meliputi putusan setiap proses dimana para pihak yang berperkara tunduk terhadap dan mematuhi proses tersebut. Lihat Mahkamah Agung, SEMA No. 3 Tahun 2002 Tentang Penanganan Perkara yang berkaitan dengan Azas Nebis In Idem. Tanggal 30 Januari 2002.

11 "Tidak ada yang harus menghadapi lebih dari satu tuntutan untuk pelanggaran yang sama, dan tidak ada yang harus dihukum dua kali untuk pelanggaran yang sama". Secara prinsip, azas ini hanya tidak dapat berlaku bagi perkara pidana yang termasuk dalam isi sebuah perjanjian ekstradisi antar negara. Dengan demikian, secara nasional azas ini harus berlaku sebagai"ius puniendi of the state and as such is part of the principles of due law and fair trial". Soal peradilan mana yang dimaksud, adalah peradilan dimana para pihak tunduk atas proses dan yang memberikannya sebuah keputusan yang adil. Lihat John A.E. Vervaele, "The Transnational Ne Bis In Idem Principle In The EU Mutual Recognition And Equivalent Protection Of Human Rights", dalam Utrech Law Review, Published by Igitur at http://www.utrechtlawreview.org/, Volume 1, Issue 2, December 2005, hal. 100.

12 Berdasarkan Laporan Tahunan Mahkamah Agung Republik Indonesia, dapat diketahui bahwa selama tahun 2010, Selama tahun 2010, perkara yang masuk ke pengadilan tingkat pertama di seluruh Indonesia berjumlah 3.037.036 perkara. Jumlah ini turun $14 \%$ dari tahun 2009 yang berjumlah 3.531 .613 perkara. Sementara itu sisa tahun 2009 berjumlah 104.444 perkara, sehingga jumlah keseluruhan perkara yang ditangani oleh pengadilan tahun 2010 berjumlah 3.141.480 perkara. Dari keseluruhan jumlah tersebut perkara yang berhasil diputus 
saja bertentangan dengan azas peradilan sederhana, cepat dan biaya ringan. sementara di sisi yang lainnya, penumpukan perkara di pengadilan pada akhirnya akan mengakibatkan fokus konsentrasi penyelesaian perkara terbatas hanya "pada hal-hal yang sifatnya tekhnis dan menjauh dari wacana (untuk memperoleh) keadilan (yang lebih mengedepankan nilai-nilai) moral", 13 sehingga cenderung hanya melahirkan keadilan formal ketimbang keadilan substansial (kebenaran materil). Persoalan ini juga menjadi alasan lain untuk memberlakukan konsep mediasi dalam perkara pidana disamping persoalan pokok tentang keadilan sebagaimana telah disinggung sebelumnya.

Mediasi dalam perkara pidana atau mediasi penal sebagai upaya peneyelesaian perkara pidana selain melalui proses persidangan di pengadilan, merupakan perubahan yang dipandang cukup signifikan dalam kerangka sistem peradilan pidana. Di beberapa negara seperti Austria, Belgia, Jerman, Perancis, Polandia, Malaysia, dan Latvia, konsep ini telah lama dan sedang terus berkembang dengan corak hukum serta pelaksanaannya masingmasing untuk memperbaharui sistem peradilan baik due process model maupun crime control model sesuai dengan yang dianutnya. Bahkan, masalah mediasi dalam perkara pidana ini, sebetulnya telah menjadi bagian dari pembahasan-pembahasan di tingkat Internasional, antara lain dalam Kongres PBB ke-9 pada tahun 1955 serta Kongres ke-10 tahun 2000 mengenai "Prevention of Crime and the Treatment of Offenders". Selain itu, telah pula diadakan Konferensi Internasional mengenai Pembaharuan Hukum Pidana (International Penal Reform Conferencee) pada tahun 1999. Hasil dari pertemuan internasional tersebut kemudian mendorong untuk lahirnya instrumen internasional tentang mediasi dalam

berjumlah 3.028.916 perkara, sehingga sisa perkara pada akhir Desember 2010 berjumlah 112.564 perkara. Lihat Mahkamah Agung RI, Laporan Tahunan 2010, Mahkamah Agung RI, Februari 2011, hal. 56. ${ }^{13}$ Yesmil Anwar dan Adang, Op, Cit., hal. 3 .

${ }^{13}$ Yesmil Anwar dan Adang, Op, Cit., hal. 3. 
perkara pidana sebagai konsekwensi dari munculnya konsep peradilan restoratif, diantaranya:

1. The Recomendation of the Counsil of Europe 1999 No. R (99) tentang Mediation in Penal Matters;

2. The EU Framework Decision 2001 tentang "The Standing of Victims in Criminal Proceedings, dan;

3. The UN Principles 2002 (draft Ecosoc) tentang Basic Principles on the Use of Restorative Justice Programes in Criminal Matters.

Berdasarkan pada beberapan instrumen internasional tersebut di atas, diketahui pula bahwa alasan lain yang mendorong untuk memberlakukan prosedur mediasi penal dalam perkara pidana adalah gagasan "restorative justice" (keadilan restoratif), ${ }^{14}$ sebagaimana dalam The UN Principles 2002 tentang Basic Principles on the Use of Restorative Justice Programes in Criminal Matters.

Prinsip keadilan restoratif ini pada intinya mengkhendaki bahwa entitas peradilan lebih mempertajam analisis hukum serta memperpeka naluri keadilan berdasarkan kepada nurani kemanusiaan dan nilai-nilai moral. Peradilan harus menjadi sebuah lembaga yang dapat menjadi sarana pemerataan keadilan, dengan memberikan peluang yang cukup bagi kehendak individu untuk mengenali dan mewujudkan keadilan yang mereka butuhkan. Proses peradilan pidana diharapkan menjadi "laboratorium akal sehat", untuk menguji kebenaran fakta hukum dengan parameter-parameter hukum

14 Menindaklanjuti prinsip "restorative justice" ini, Sahuri Lasmadi menyimpulkan bahwa dalam sebuah peradilan pidana yang menganut prinsip restorative justice, harus ada keterlibatan semua pihak yang mengambil bagian dan secara bersama-sama memikirkan bagaimana cara terbaik untuk menghadapi suatu masalah, baik terhadap akibat yang ditimbulkan maupun sistem pencegahan yang tepat untuk digunakan di masa mendatang. Dengan demikian, pendekatan restorasi dalam peradilan seperti ini mengedepankan hasil yang berupa perbaikan (reparation) atas akibat suatu tindak pidana, serta pencegahan (prevention) ketimbang menjatuhkan sanksi pidana. Lihat Sahuri Lasmadi, “Pertanggungjawaban Korporasi Dalam Perspektif Kebijakan Hukum Pidana Indonesia", Disertasi Doktor Pasca Sarjana Universitas Airlangga, Surabaya, 2003, hal. 185. 
dan hati nurani terdalam dari manusia, sehingga menghasilkan kebenaran dan keadilan bagi pelaku dan korban, lebih jauh lagi dapat memenuhi rasa keadilan bagi masyarakat pada umumnya, juga demi tegaknya kedaulatan hukum dan keadilan yang utuh dalam tatanan kehidupan masyarakat.

Sejalan dengan semangat dunia internasional untuk menerapkan mediasi penal dalam sistem peradilan pidana, diskursus serupa juga mulai berkembang di Indonesia. Konsep ini oleh para ahli hukum dipandang sangat relevan dan cocok untuk diberlakukan di Indonesia. Lilik Mulyadi misalnya yang menganalisa masalah ini dalam perspektif filosofis. Dalam perspektif ini, prinsip win-win solution (menang-menang) yang merupakan asas mediasi penal, maka dapat diperoleh puncak keadilan tertinggi karena terjadinya kesepakatan mengenai bentuk penyelesaian perkara antara para pihak yang bersengketa. Konsep ini tentu berbeda dengan apa yang diperoleh melalui jalur litigasi (peradilan), di mana penyelesaian sengketa berakhir dengan situasi "menang-kalah" (win-lost) atau "kalah-kalah" (lost-lost). Hal tersebut sejalan pula dengan aspek sosiologis bangsa Indonesia, bahwa mediasi penal sesungguhnya merupakan cerminan dari akar budaya masyarakat Indonesia yang berorientasi pada kekeluargaan dengan mengedepankan asas musyawarah mufakat untuk menyelesaikan sengketa dalam suatu sistem sosial. ${ }^{15}$

Ditinjau secara historis, sebetulnya mediasi penal telah lama dikenal sebagai kearifan lokal dari waktu ke waktu dalam hukum adat di Indonesia yang berlandaskan pada alam pikiran kosmis, magis dan religius sebagaimana dapat ditemukan di Sumatera Barat, Aceh, Lampung serta pada hukum adat di daerah lainnya, meskipun dengan istilah dan dalam bentuk pelaksanaan yang beragam. Bahkan lebih jauh lagi, bangsa

${ }^{15}$ Lilik Mulyadi, “Penyelesaian Perkara Di Luar Pengadilan Melalui Dimensi Mediasi Penal (Penal Mediation) Dalam Sistem Peradilan Pidana Indonesia", Makalah. Penelitian untuk wilayah Pengadilan Tinggi Palangkaraya, Mataram, Jambi dan Semarang, Badan Litbang Diklat Kumdamil Mahkamah Agung RI, April-Mei 2011. 
Indonesia telah memiliki lembaga peradilan pidana kontemporer yang berorientasi tidak semata-mata hanya pada penjatuhan pidana, melainkan lebih kepada penanggulangan terhadap kegoncangan magis dalam masyarakat sosial yang disebut dengan Lembaga Pemberian Maaf.

Dari kedua sudut pandang yang demikian, dapatlah dikatakan bahwa sesungguhnya mediasi penal merupakan ciri khas dan mekanisme utama bangsa Indonesia dalam menyelesaikan permasalahan di dalam sistem sosialnya, khususnya dalam persoalan pidana. Jika saat ini dikatakan bahwa mediasi penal merupakan hal yang baru dan bahkan diantara pendapat ada yang menyatakan tidak dikenal, agaknya pendapat tersebut keliru. Sebaliknya, justru upaya pengejawantahkan mediasi penal dalam sistem peradilan pidana adalah suatu upaya mengembalikan tatanan kaedahkaedah hukum dan keadilan kepada sejatinya bangsa Indonesia sendiri.

Penolakan atas wacana memasukan prosedur mediasi penal sebagai bagian dari mekanisme sistem peradilan pidana Indonesia, memang dapat dimaklumi jika mendasarkan argumentasi tersebut pada ketentuan hukum positif Indonesia saat ini. Tidak ada satupun undang-undang yang secara eksplisit memberikan aturan bagi terjadinya mediasi untuk menyelesaikan perkara pidana. Sekalipun Indonesia memiliki Undang-Undang Nomor 30 Tahun 1999 tentang Arbitrase dan Alternatif Penyelesaian Sengketa, undangundang ini hanya melingkupi ranah hukum perdata belaka. Dengan demikian untuk perkara pidana pada prinsipnya tidak dapat diselesaikan melalui mekanisme selain dari proses di sidang pengadilan, atau jenis ADR lainnya.

Meskipun demikian Barda Nawawi Arief menyebutkan, bahwa dalam hal-hal tertentu dimungkinkan adanya penyelesaian kasus pidana di luar pengadilan. Misalnya bilamana delik yang dilakukan berupa "pelanggaran yang 
diancam dengan pidana denda". ${ }^{16}$ Jika demikian, maka sesuai dengan ketentuan Pasal 82 KUHP, apabila terdakwa telah membayar denda maksimum untuk delik tersebut, serta membayar biaya-biaya yang dikeleluarkan apabila penuntutan telah dilakukan, maka kewenangan/hak menuntut atas delik tersebut menjadi hapus. Demikian juga dengan ketentuan dalam Undang-Undang Nomor 3 Tahun 1997 tentang Pengadilan Anak.

Dalam Pasal 5 undang-undang ini disebutkan bahwa terhadap anak di bawah 8 tahun yang melakukan tindak pidana, maka penyidik dapat menyerahkan anak tersebut kepada orang tua, wali atau orang tua asuh apabila dipandang masih dapat dibina. Akan tetapi kemungkinan-kemungkinan tersebut belum merupakan mediasi penal serta tidak pula secara tegas menggambarkan kemungkinan adanya mediasi antara pelaku dengan korban.

Sekalipun dalam tataran yuridis di Indonesia memang tidak ada ketentuan hukum yang secara tegas mengatur dan memberikan peluang untuk terjadinya penyelesaian perkara pidana di luar pengadilan, namun dalam tataran praktiknya sering terjadi penghentian suatu perkara pidana sebelum dilakukan proses penuntutan di pengadilan melalui diskresi aparat kepolisian.

Diskresi inipun sebetulnya hampir tanpa dasar sebelum akhirnya keluar Surat Kapolri No. Pol: B/3022/XII/2009/ SDEOPS tanggal 14 Desember 2009 tentang Penanganan Kasus Melalui Alternatif Dispute Resolution (ADR). Surat Kapolri ini dapat dikatakan sebagai aturan pertama yang secara tegas mengatur masalah mediasi penal meskipun secara parsial dan terbatas sifatnya. Lagipula kekuatan hukum Surat Kapolri tentu tidak sebanding dengan kekuatan hukum yang dimiliki oleh suatu undang-undang.

${ }^{16}$ Ibid. 